\title{
Early assessments of marine governance transformations: insights and recommendations for implementing new fisheries management regimes
}

\author{
Stefan Gelcich $^{1}$, Francisca Reyes-Mendy ${ }^{2}$ and Monica A. Rios ${ }^{3}$
}

\begin{abstract}
Implementing a governance transformation entails the creation of a new institutional system when ecological, economic, or social structures make the existing system untenable. It involves building capacities, establishing viable formal and informal institutions, and triggering major societal changes. Early assessments (EAs) provide a mechanism to fine-tune and support institutional learning processes, which are needed to provide legitimacy and political acceptability of transformational change. We performed an EA of a governance transformation aimed at implementing ecosystem-based, multilevel participatory fisheries management in Chile. We performed individual interviews and workshops and synthesized existing reports to assess the main challenges of the institutionalization of the new policy. Results showed that successful implementation of the governance transformation would need to address key issues related to building trust and improving transparency, including clear protocols for cocreating knowledge and securing resources and capacities. The EA allowed us to define specific recommendations associated with legal reforms, issuing of new executive orders to clarify implementation, and improvement in operational standards by government agencies. EAs provide a fundamental tool that helps build legitimacy and sustainability of new governance systems. They bring a sense of reality, informed by social science, that allows us to understand progress in the implementation of governance transformations, by identifying rigidities that fail to accommodate emerging realities.
\end{abstract}

Key Words: Chile; coproduction of knowledge; governance transformation; marine management; policy implementation; trust building

\section{INTRODUCTION}

Fisheries resources are key to economic, social, and environmental well-being. By nature, they are easily available (open access and low entry cost) to multiple and very diverse users, composing a complex social-ecological system that imposes severe governance challenges (Ostrom 1990). Countries around the world have long struggled to generate rules and regulations to avoid overexploitation, such as total allowable catch, individual tradable quotas, and vessel and gear restrictions, as well as ad hoc public institutions for enforcement and research. However, these regulations have not always been successful in achieving their objective, as is evident from the fact that a significant proportion of the world's marine resources are overexploited or have collapsed (Food and Agriculture Organization of the United Nations [FAO] 2016).

The degraded state of the oceans and marine resources together with the need to balance competing uses have prompted numerous international efforts to address the challenge of marine sustainability. During the last decades, global environmental policy discussions have led countries to try to adopt an ecosystembased approach to fisheries management (Convention on Biological Diversity 2011, FAO 2015) that involves the integrated management of species, other natural commodities/services, and multiple human coastal uses. As an ecosystem-based management (EBM) approach is being promoted, it has become increasingly clear that incremental changes and adaptations of current development pathways may not be sufficient to achieve the sustainability goals behind EBM (Gelcich et al. 2010, Westley et al. 2011) and that an effective local implementation of the EBM approach needs a process of governance transformation (Gunderson and Holling 2002, Olsson et al. 2008, Gelcich et al. 2010) that not only adopts a new vision of fisheries management but also adjusts the governance system (by whom and how decisions are made) while developing the capacity to frequently update policy objectives.

In the last decade, there has been an increasing interest in transformations (Gunderson and Holling 2002) of socialecological systems from unsustainable development pathways toward more sustainable ones (Walker et al. 2009, Folke et al. 2010). As part of this trend, scholars have raised awareness of the need to address issues of governance transformations in natural resource management (Olsson et al. 2006, 2008, Gelcich et al. 2010). Form a social-ecological standpoint, a governance transformation entails the capacity to create a new institutional system when ecological, economic, or social structures make the existing system untenable (Walker et al. 2004). A governance transformation modifies public policy objectives and includes new management visions and actors in a reformed decisionmaking process (Olsson et al. 2008, Cerna 2013). Hence, governance transformations differ from new policies that entail incremental shifts in existing structures (Bennett and Howlett 1992).

Most studies of governance transformations toward more participatory and ecosystem-based fisheries management have focused on conditions determining the transformation (Olsson et al. 2008, Gelcich et al. 2010, Ayers and Kittinger 2014), provided

\footnotetext{
${ }^{1}$ Departamento de Ecología, Center of Applied Ecology and Sustainability (CAPES), Center for the Study of Multiple-Drivers on Marine SocioEcological Systems, Pontificia Universidad Católica de Chile, Santiago, Chile, ${ }^{2}$ Instituto de Ciencia Política, Center for Applied Ecology and Sustainability (CAPES), Pontificia Universidad Católica de Chile, Santiago, Chile, ${ }^{3}$ Center of Applied Ecology and Sustainability (CAPES), Pontificia Universidad Católica de Chile, Santiago, Chile
} 
meta-analyses of cases gleaned from the literature (Evans et al. 2011, Gutiérrez et al. 2011), or quantitatively examined how key social and ecological outcomes associated with governance transformations change once policies have been implemented for years (Evans et al. 2011, Cinner and McClanahan 2015, Gelcich et al. 2017). These studies have been important to build theory about the process and phases of transformative change. In fact, using a social-ecological systems perspective, scholarship has conceptualized transformations as including the existence of a series of steps or phases that include trigger events, actors preparing for change, navigating a transition, and institutionalizing a new system trajectory (Olsson et al. 2004, Moore et al. 2014). This last phase puts emphasis on the need to institutionalize any new trajectory (Moore et al. 2014) and is critical for the new governance regime to be correctly implemented, persist, and increase its legitimacy. The nature of governance transformations suggests that an early assessment (EA) of the new institutional model and decision-making process is critical to address institutionalization problems and fine-tune the process through which governance transformations can be successfully implemented.

For our purposes, we define EA as the evaluation of the first stage of the implementation phase of the public policy process. An EA of the institutionalization phase of a governance transformation potentially allows us to identify problems in policy design and implementation. EAs provide the opportunity to raise and address questions related to the political acceptability of governance transformations to adjust the focus of processes that are not being carried out adequately, clarify responsibilities, and allow for institutional learning, which are key for the correct institutionalization of transformative changes. As such, EAs provide a mechanism to fine-tune and support institutional learning processes that are needed to provide minimum levels of legitimacy and political acceptability. The EA process must be carried out shortly after beginning the implementation of policy changes that by their very nature will support, if fully implemented, a governance transformation. As such, EAs are a useful tool to timely evaluate these governance transformations, particularly focusing on by whom (the actors) and how (the decision-making process) new policy objectives are accomplished.

In Chile, a governance transformation toward EBM and multilevel participatory governance is being institutionalized with the implementation of the management plan policy, an institutional instrument contained in the new fisheries law (Law No. 20.657; Ministerio de Economía, Fomento y Turismo, Subsecretaría de Pesca y Acuicultura 2013). The management plan legal framework explicitly aims to include EBM principles by allowing the mix of "top-down" directives from government with "bottom-up" approaches in which fishers participate directly in policy implementation (Gelcich et al. 2015, FAO 2016). The enactment of Law No. 20.657 in Chile created a new decisionmaking process that integrated existing institutions with new ones. One key feature of this law was the creation of a new participatory arena, namely, management committees, which are responsible for the design of fishery management plans and in which stakeholders are represented. Another important feature relates to the functioning of scientific committees (Ríos 2015). In essence, the governance transformation has required adapting roles and functions of existing institutions to the new policy objectives challenging traditional institutional roles and expertise and modifying the relations between public and private actors (Reyes et al. 2017).

The recent governance transformation in Chile provides a unique opportunity to explore the role of EA as a public policy tool that improves the policy implementation phase of governance transformations aimed at addressing EBM. The EA of the institutionalization phase of governance transformations should allow us to identify and address issues that might undermine their political acceptability and avoid unintended outcomes. We explore the role of EA in governance transformation implementation by grounding our research in the Chilean management plan fisheries policy.

\section{Early assessment of governance transformations: the case of Chilean fisheries}

The very nature of a governance transformation suggests that if a new regime is going to be institutionalized, the implementation of a policy, defined by Pressman and Wildavsky (1984:xxiii) as "a process of interaction between the setting of goals and actions geared to achieving them," needs an EA, not only of its contents but also of its processes and general acceptability. The implementation of a governance transformation entails a policy process in which decisions are taken by new or reformed actors in a novel decision-making setting. Thus, one would expect EAs of governance transformations to explore the changing role of existing actors and the inclusion of new actors to the recently created institutional design, as well as the functioning of the new decision-making processes.

In Chile, a first transformation toward EBM took place during the 1990s in the form of a comanagement approach, which resulted in a revolutionary national system that allocates exclusive territorial user rights to artisanal fisher associations for the management of benthic resources (Gelcich et al. 2010). More recently, in 2013, Chile passed new legislation that further transforms fisheries governance. The policy attempts to define long-term objectives, applying the precautionary principle, adopting an EBM approach, and adopting best practices to increase transparency and public information. A key element of this policy is the creation of what have been termed management plans. These management plans can be established for all fisheries, comprising benthic, pelagic, and demersal, including those shared between industrial and artisanal fleets (Law No. 20.657, article 8; Ministerio de Economía, Fomento y Turismo, Subsecretaría de Pesca y Acuicultura 2013). The management plan policy essentially allows the management of a species or group of species within a bay, an administrative region, part of a region, or a set of regions through the establishment of management committees, which include both artisanal and industrial fishers and government officers (see Gelcich [2014] for a full description of the policy). It essentially gives the role of coordinator/facilitator to the Undersecretariat for Fisheries (Subsecretaría de Pesca y Acuicultura [Subpesca]), the government agency in charge of public policy and regulation, in the new decision-making process. The policy also increases the role of biophysical science, establishing the binding nature of scientific committees' recommendations when determining the total allowable catch for fisheries. 
Before the shift toward the management plan policy, an institution named the Chilean National Fisheries Council was responsible for making decisions on annual global catch quotas, i.e., total allowable catch. Fishers and other interest groups were represented in the national council, and the final quota was approved by a majority of the council members (Leal et al. 2010). The National Fisheries Council generally increased the quota proposed in technical reports by an average of $32 \%$ for social and economic reasons, putting at risk resource sustainability (Leal et al. 2010). The management plan policy changed the decisionmaking process of the total allowable catch for fisheries, giving a greater role to science in the decision-making process by creating a new actor, the Technical Scientific Committee, which was responsible for providing the Undersecretariat for Fisheries with the basic and binding scientific information, based on maximum sustainable yields, to make the final decision for the overall total allowable catch.

A key feature of the law was the creation of the management committees that became responsible for the elaboration of fishery management plans enacted with the participation of all the actors interested in the resource (Gelcich 2014). Management plans must contain the following: (1) general background information on the geographic area, types of resource, fishing fleets, and markets; (2) clear objectives, goals, and time frame to maintain fisheries at maximum sustainable yield; (3) strategies to achieve objectives and goals, which must include conservation and management strategies and agreements between stakeholders; (4) evaluation criteria for management plans; (5) contingency strategies; and (6) research and enforcement requirements (Gelcich 2014).

In essence, the governance transformation focused on EBM as a guiding principle and entailed a profound change from the previous improvements in fisheries policies (see Gelcich et al. [2018] for a review of incremental advances in Chilean fisheries policy). It coupled new goals with the creation of new institutional actors, i.e., the management and scientific committees, while also assigning new roles and responsibilities to existing institutions. The magnitude of the changes introduced by this new legislation called for an EA to secure the correct implementation of the governance transformation.

\section{METHODS}

The EA process targeted the implementation of the new fishing regulation passed toward the end of 2013, with emphasis on the shifting role of actors/institutions and decision-making processes. The EA consisted of a three stage sequential process in which mixed methods were used and that began with an initial diagnosis based on expert judgment, case study analyses, interviews, and official or unofficial reports and documents. A second stage aimed at receiving feedback and redefining the main issues raised in the initial diagnosis with a set of stakeholders, through individual, in-depth, semistructured interviews and open discussions in a workshop that focused on the main challenges and changes needed to improve implementation. The last stage aimed at proposing and validating specific recommendations with stakeholders using expert judgment, individual interviews, and a workshop. Figure 1 synthesizes the main methods used in each stage.

The first stage focused on generating a preliminary diagnosis of the main challenges and problems actors faced in adopting the new regulatory framework. To that end, the new fishing regulation was analyzed using official and unofficial reports and documents, as well as expert judgment, to produce an initial framing for guiding our sampling criteria, interview content, and case study analysis. Guiding themes included the following: (1) the adaptation of roles and functions of existing institutions to new policy objectives and decision-making processes; (2) the inclusion of new or competing actors to the recently created institutional design; and (3) the functioning of the new decision-making processes. Using the guiding themes as a road map, we analyzed the functioning of three key management plans, namely, those of the southern hake or Merluza austral (Merluccius australis), the common hake or Merluza común (Merluccius gayi), and the benthic bivalve resources (the bivalve clams huepo [Ensis macha], navajuela [Tagelus dombeii], and taquilla [Mulinia edulis]) in the Gulf of Arauco. The two hake case studies were selected because they were in the most advanced stage of progress and because the fish stocks were shared among artisanal and industrial fishers. The Gulf of Arauco case study was selected because it was one of the first benthic resource, artisanal fishery management plans. Management plan analysis was based on the review of the minutes of the management committees' meetings, which are available online at Subpesca's website (http://www.subpesca.cl/portal/615/ w3-propertyvalue-38010.html), and interviews with key stakeholders per plan $(n=12)$. This stage focused on exploring how existing and new actors behaved, specifically focusing on what role they played and the kind of information they provided to the management committee. Interviews with members of management plans and government representatives targeted main problems, clarity in processes, roles and responsibilities, and ways in which different roles were being performed. The analysis of the minutes targeted how decisions were made, how different kinds of knowledge and participation of new and preexisting actors were being managed, the types of conflicts that emerged, and agreements that were achieved. The result of this first stage created a preliminary diagnosis: new and existing actors faced problems of trust, participation, and access to information in the decisionmaking process, and there were a number of issues related to which kind of knowledge was being used and how it was produced and delivered. This preliminary diagnosis needed to be tested and further refined in a second stage.

The second stage aimed at receiving feedback and redefining the preliminary diagnosis, with a set of stakeholders, through individual, in-depth, semistructured interviews and open discussion in a workshop, of the main challenges and changes needed to improve implementation. This stage consisted of a workshop conducted to elicit opinions and share early findings allowing stakeholders to participate in an open discussion that allowed different visions to be shared and debated. Workshop participants included government officers in charge of conducting the implementation of the new regulation, scientists who acquired a more relevant and influential role in decision making, and industrial and artisanal fishers who were required to play by new rules. The purpose of this workshop was to present the initial diagnosis for validation and at the same time to gather new opinions and perspectives that deepened and somehow redefined the key implementation problems. With the results of the workshop, a set of semistructured, in-depth interviews was conducted with 20 different individuals from various stakeholder 
Fig. 1. Research stages and methods used for the early assessment of the Chilean fisheries governance transformation.

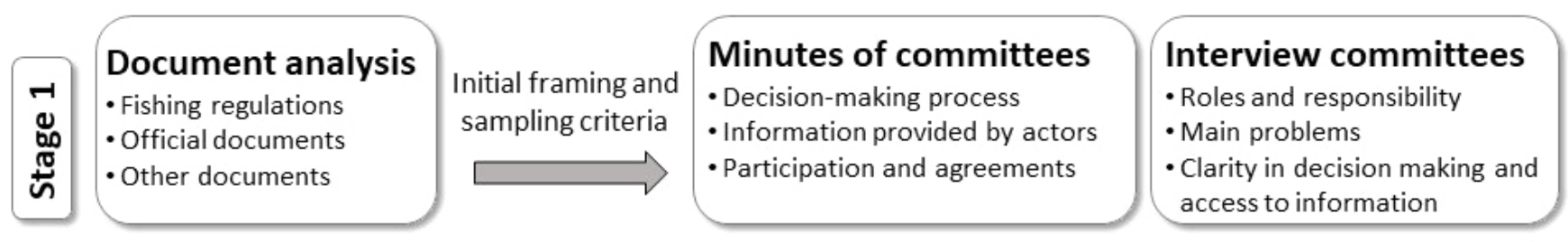

\section{Diagnosis of key issues}

\section{Workshop 1}

- Multiple stakeholders

- Review diagnosis

- Main challenges: open deliberation

- Redefine implementation problems

\section{Semistructured interviews}

- Multiple stakeholders

- Knowledge: delivery, management, synthesize

- Improvement: trust, participation, information

- Challenges for legitimacy and suggestions

\section{Challenges and changes for improved implementation}

\section{Compared experience}

- Review of international experiences:

- Delivery and diversification of knowledge

- Participation and access to information

\author{
Semistructured interviews \\ - Multiple stakeholders \\ - Level and types of changes needed \\ (law, regulations, operation) \\ - Expected responsible for changes
}

\section{Workshop}

-Types of changes needed:

- Legal

- Executive orders

- Operational standards groups. Interviews focused on the two main items gathered at the workshop: (1) how knowledge was managed and how the creation and delivery of different types of knowledge could be improved, and (2) how the decision-making process in terms of trust, participation, and access to information was functioning and could be improved. To select interviewees, we first identified 8 different stakeholder groups that directly or indirectly participated or had played a role in the functioning of the new institutional model. Stakeholders included public-sector institutions, e.g., Subpesca; artisanal fishers/industrial fishers enforcement agency, i.e., Servicio Nacional de Pesca y Acuicultura (Sernapesca); and institutions that provide scientific information, e.g., Instituto de Fomento Pesquero (IFOP), universities, and marine-focused nongovernmental organizations (NGOs). Key representatives in each group were interviewed. As part of the EA process, some interviewees were interviewed more than once. This second stage allowed us to capture the technical and political challenges of the governance transformation and concluded with a more nuanced and refined diagnosis and with the addition of a set of concerns regarding the relevance of resources and capacities needed for the correct implementation of the new governance regime.
The last stage generated and then validated specific recommendations needed to improve the institutionalization phase of the governance transformation. Recommendations included legal reforms, issuing of new executive orders to clarify implementation, and/or improvement in operational standards by government agencies. A comparative study on how selected case studies, i.e., countries, addressed the challenges of creation, delivery, and diversification of knowledge and trust; participation; and access to information of different stakeholders in the decision-making process was conducted as a complement to stakeholders' recommendations, which came from a series of interviews with key actors, a workshop, and the synthesis of all information gathered. The building of recommendations included stakeholders' participation in detailing the level and types of changes needed, as well as the expected party responsible for implementing changes. A final workshop took place to share and validate the final diagnosis and the recommendations for change from the EA process.

\section{RESULTS}

The results of the EA process identified various key issues regarding the implementation of the new governance process. These issues can be divided into two main areas that specifically 
Table 1. Key issues identified during the early assessment process.

\begin{tabular}{ll}
\hline \hline Main Areas & Key Issues \\
\hline Governance process: actors & $\begin{array}{l}\text { Trust building among the key stakeholders in each } \\
\text { fishery (industrial/artisanal) and among the key } \\
\text { stakeholders and the new institutional model. } \\
\text { Achieving adequate participation and }\end{array}$ \\
& $\begin{array}{l}\text { representativeness of all key stakeholders in the } \\
\text { management of the fishery. }\end{array}$ \\
& $\begin{array}{l}\text { Coproduction of knowledge: being able to successfully } \\
\text { integrate different types of knowledge (scientific/local/ } \\
\text { bovernance process: decision-making process }\end{array}$ \\
& $\begin{array}{l}\text { Guarantee the resources and capacities necessary for } \\
\text { the correct implementation of the new model. }\end{array}$ \\
\hline
\end{tabular}

relate to (1) the way new and existing actors adapt to their roles and to the new institutional design and (2) the adoption of the novel decision-making process. In addition, a third area that emerged from the EA emphasized the importance of guaranteeing the necessary monetary resources and capacities for the correct implementation of the new institutional model (Table 1).

\section{Actors: the challenge of building trust and achieving adequate participation and representativeness of stakeholders in the management of the fishery}

The EA highlighted that a key issue in accomplishing the proposed governance transformation is to address mistrust. Mistrust was detected between artisanal and industrial fishers, but also between fishers and the representatives of government agencies, particularly of Subpesca. The lack of trust was inherited from the previous institutional model, which suffered from a progressive delegitimation mainly because the decision-making process to set total allowable catch limits, formerly led by Subpesca, was widely perceived as opaque and discretionary. Some studies have concluded that often allowable catch limits were set higher than scientific recommendations (Leal et al. 2010) because of the pressure exerted by various interest groups, basically industrial and artisanal fishers. The newly installed decision-making process was designed precisely to neutralize this mistrust as it carefully considered a new, stronger, and impartial role for science, granting responsibility for the allowable catch limits to the newly created scientific committees.

However, mistrust prevailed, and evidence from the EA grounded in the management plans of the common hake, the southern hake, and benthic resources showed the following: (1) lack of confidence in the selection of the members comprising the management committees and (2) absence of standardized procedures to report the work of the management committees, especially because of conflicting opinions among the members. The lack of clear protocols increased the risk of resistance by actors and institutions toward the governance transformation.

Regarding the selection of management committee members, the EA process clearly identified that the current regulation that mandates a fixed number of members per management committee was unable to capture differences between fisheries, leaving out key actors, i.e., in fisheries including a wide geographic area, such as common hake, or including unnecessary actors, thus distorting the legitimacy of the process. Different sizes and geographic locations of specific fisheries call for different arrays of stakeholder configurations in management committees. Thus, a certain degree of flexibility in the composition of the management committee seems advisable to accommodate the particularities of each management plan. In addition to including flexibility in the number and types of fishers involved, flexibility is needed to allow the permanent inclusion of new members such as Directemar, a subagency of the Chilean Navy in charge of enforcement and control in the sea that was reported to be a key member for fisheries facing the ravages of illegal fishing, i.e., common hake, or the incorporation of temporary members such as those related to certification, education, tourism, development, and labor aspects, which can provide input at key stages.

The EA also highlighted issues of representativeness. Interviews identified concerns about the degree of representativeness of some artisanal fisher members in the management committees, because in some cases these representatives were not fishers but fish dealers, suggesting the need to include transparency and accountability standards for their election process, as well as to formalize and strengthen the supervisory role of the fishing authority. This lack of transparency in representativeness reinforces power inequalities that might jeopardize the system. Regarding representativeness of government agencies, during some of the interviews and workshops, the disparity in technical capacities, different hierarchies, and nonuniform interpretation of their role in the management committees were highlighted. The recommendation is that Subpesca should provide definitions of the expected or desired characteristics and tasks to be accomplished by these representatives and coordinate training workshops to improve leadership skills in the management committee.

Interestingly, the EA process also identified the absence of standardized procedures to report the work of the management committees as a potentially very damaging source of mistrust and delegitimation. Thus, from a trust building perspective, a set of recommendations includes the development of a guideline to standardize the minimum contents of the minutes, including the obligation to report consensus and discrepant points among the members of the management committee on a timely basis. This type of practice will help to avoid the perception that the management committee is working behind "closed doors" and allow all interested parties, such as NGOs, academics, and industrial and artisanal fishers that are not part of the committee, 
to follow the discussion and have access to this information. Increased accountability of the representatives' work would also be accomplished.

The EA highlighted the need for annual working plans of management committees to be public, including contents and schedule. In the feedback and redefinition phase of the EA, stakeholders reported the importance of being informed on a timely basis about the new measures and impacts of these plans. Better communication about the contents of the approved management plan should contribute to better understanding and a better implementation process. The specific recommendation is to develop a guideline to standardize the work of the management committee, including a communications plan. Thus, for the institutionalization of governance transformations, developing transparency protocols seems a key feature to ensure scalability and increased legitimacy.

\section{Decision-making process: the challenge of building and integrating different types of knowledge}

One of the cornerstones of the new governance model was timely access to reliable scientific knowledge. In fact, the new law indicates that IFOP, the national fisheries institute, should be the permanent adviser of Subpesca and should provide the basic research needed for regulation of the fishing sector. Nevertheless, during the EA process, difficulties in obtaining certain scientific data were identified, highlighting the need to improve practices to comply with the transparency bill enacted in 2008 (Law No. 20.285) and with specific transparency requirements set by the 2013 fisheries law itself.

This unfulfilled need for timely scientific information was also revealed in constant requests of the management committees to meet with the scientific committees, particularly in the case of the southern hake. Paradoxically, and to eradicate any similarities with the "old decision-making" model, the Undersecretariat for Fisheries prohibited almost any contact between the scientific and the management committees, which in practice inhibited the exchange and discussion of available information and knowledge, negatively affecting the quality of decision making. This lack of communication and mistrust implies that Subpesca should internalize and adopt the basic principles of EBM, which require participation and cocreation of knowledge. A solution proposed in the EA was to modify "bylaws" to require a minimum number of joint working sessions.

To fulfill the transition toward an EBM approach in fisheries management, it is crucial to generate a decision-making process that allows for the incorporation of different types of knowledge. Coproduction of knowledge, described as the interaction of different knowledge and domains with the aim of "exchanging, combining and harmonizing elements like facts, interpretations, assumptions and causal relations from their different knowledge domains" (Edelenbos et al. 2011:676), is a key element to this approach. Nevertheless, during the EA process it became evident that the focus of the new institutional model was still on biophysical scientific knowledge, basically biological aspects. Other types of knowledge are only being provided to a limited degree by different actors, i.e., economic knowledge by industrial fishers and some social knowledge by artisanal fishers. In the case of local knowledge, which was reported to be provided by artisanal fishers, it is crucial to support a process of systematization and validation of such knowledge for it to be useful for the work of the management committees. Bureaucratic knowledge is mainly available from government agencies, particularly from Sernapesca. A recommendation for Subpesca is to evolve toward a more multidisciplinary working team to provide socioeconomic information relevant for the management of fisheries and thus support the work done by the management committees in a permanent and more effective way. According to the EA, there is a need to strengthen the work of the department "Unidad de análisis sectorial" in Subpesca, which does some basic work in these areas. Finally, the EA establishes that scheduling public hearings to receive information from NGOs and other interested parties working on these topics, as well as the community in general, seems advisable. In essence, the EA allowed us to identify critical barriers and leverage points regarding the way knowledge is included in EBM. Recommendations are key to avoiding the resistance of actors such as government officials who might feel the need to block some elements of the institutionalization of the governance transformation toward EBM.

\section{Resources and capacities for the correct implementation of the new model}

During the interviews and workshops conducted as part of the feedback, redefinition, and validation stages of the EA, key actors reported that having limited resources and capacities to timely and adequately elaborate the management plans was a risky situation, which could lead to the very early delegitimation of a still nonlegitimized model. As one representative of the Undersecretariat for Fisheries recognized, "In order to achieve greater participation and better instances of participation, which are necessary, resources [financial] and staff training is [sic] required" (benthic resources representative, Undersecretariat for Fisheries, 2016, personal communication).

The EA showed that resource and capacity limitations were partly attributable to the underestimation, by policy designers, of the impacts that the new model would impose on key historical actors such as Subpesca. In fact, the new institutional model assigned many new responsibilities and tasks to Subpesca. Foremost of these tasks is the need to act as a coordinator/facilitator of the management committees. Unfortunately, there is a lack of monetary and human resources to undertake this new role adequately. Some civil servants, not trained in facilitation, are responsible for up to three management committees. Thus, the interviews, workshops, and focus groups in the EA revealed the urgent need to increase capacities.

Moreover, the EA revealed that the new model did not consider monetary support for stakeholder participation in the management committees. This generates a risk for the autonomy and representativeness of artisanal fishers, because in some cases they cannot afford to travel, or in others, their expenses are financed by industrial fishers, increasing distrust. In the same way, the almost nonexistent monetary incentives to ensure the participation of scientific experts who are knowledgeable in stock evaluation and fisheries resources management, coupled with the stringent conflict-of-interest regulations for their participation, have jeopardized their participation in scientific committees; in seven out of eight scientific committees, vacant seats were still available. 
Table 2. Examples of key recommendations obtained from the early assessment process. IFOP, Instituto de Fomento Pesquero.

\begin{tabular}{lll}
\hline \hline Implementation Requirement & Institution & Recommendations \\
\hline Legal reform & $\begin{array}{l}\text { Management committees } \\
\text { (articles 8,9 bis, and 9A) }\end{array}$ & $\begin{array}{l}\text { Allow some degree of flexibility in the number of fishing sector representatives to } \\
\text { match the specifics of each fishery. } \\
\text { Add the maritime authority (Directemar) as a permanent member. } \\
\text { Add a new category of nonpermanent members to deal with specific issues as needed. } \\
\text { Add a representative of universities or research centers that receive public funding as } \\
\text { a permanent member. }\end{array}$ \\
& $\begin{array}{l}\text { Provide monetary incentives to ensure the independent participation of artisanal } \\
\text { representatives. }\end{array}$ \\
& $\begin{array}{l}\text { Improve monetary incentives to ensure the participation of the "best" scientists. } \\
\text { Change incompatibilities that affect scientists' ex post job opportunities. }\end{array}$
\end{tabular}

Issuing of new executive orders Scientific and management to clarify implementation
Scientific and management
committees

Establish that scientific and management committees should meet regularly to exchange information and improve analysis (Executive Orders DS No. 95-2013 and DS No. 77-2013 and their modifications)

Note: In general, all legal reforms will require the modification of the corresponding executive orders.

Improvement in the operational Undersecretariat for Fisheries standards by government agencies Supervise the election process of artisanal representatives in the management
committees.

Create job profiles for all government representatives in the management committees. Conduct training workshops for its management committees' representatives. Allocate budgetary resources for management committees to contract studies and/or hire advisers on social and economic issues.

Strengthen the "fishing analysis unit" to support the management committees' work. Systematize and validate local knowledge from artisanal fishers for management committees' work.

Elaborate an internal procedures manual for the work of the management committees' work including annual working plan, meeting schedule, and communications strategy, among others.

Ministry of Economics
Comply with its legal obligation to dictate the database management policies for IFOP, including public access.

Ensure adequate monetary and human resources for the Undersecretariat for Fisheries to comply with its new obligations.

\section{DISCUSSION}

Calls for governance transformations as a way to advance toward sustainable development have become increasingly common (Olsson et al. 2008, Gelcich et al. 2010, Evans et al. 2011, Cinner and McClanahan 2015). We have focused on the last phase of a governance transformation, the "institutionalizing the new trajectory" phase (Olsson et al. 2006, 2008, Moore et al. 2014). In this phase, new social-ecological feedbacks become established (Moore et al. 2014), and therefore, the implementation of the new governance regime must be monitored and fine-tuned to ensure legitimacy and avoid unintended consequences (Westley et al. 2013). Unfortunately, the necessary social science is rarely conducted to understand the institutionalization of governance transformations (Cinner and McClanahan 2015). Our results show that the institutionalization phase involved the redefinition of roles for old actors and the inclusion of new actors, as well as the establishment of a new decision-making process. The EA also helped identify gaps and barriers to the institutionalization of the governance transformations. In doing so, the EA was key to propose ways to fine-tune the new policy process, because it allowed us to identify conditions that must be improved for the transformation to attract widespread political acceptability and legitimacy.

EAs provide important insights into the institutionalization of a governance transformation, particularly considering the real- world constraints of actual governance contexts such as fragmented institutions, contested policy processes, and poorly delineated roles and capabilities of policy makers and administrators (Patterson et al. 2017). The EA of the new fishing law passed in 2013 (Law No. 20.657; Ministerio de Economía, Fomento y Turismo, Subsecretaría de Pesca y Acuicultura 2013) shows the redefinition of management goals, the establishment of new roles for existing actors, and the structuring of new decision-making processes. Although the law has great potential to improve EBM (Gelcich 2014), results of the EA show challenges associated with its implementation, which, if unresolved, will constrain the ability of this governance transformation to catalyze wider sustainability. In this sense, results of the EA of the fisheries law implementation suggest that successful institutionalization of a governance transformation would need to address key issues related to (1) building trust among actors and improving transparency in participation, (2) defining how different types of knowledge are cocreated and fed into the policy process, and (3) securing resources and capacities. The EA also allowed us to define recommendations associated with legal reforms, issuing of new executive orders to clarify implementation, and/or improvement in operational standards by government agencies (Table 2 for list of key recommendations).

Results of the EA highlight the need to foster and build trust in the newly created actors. In the Chilean management plan 
transformation, trust must be built in the management committees. Trust must also be built among the key stakeholders inside each fishery, i.e., industrial/artisanal, and among the key stakeholders and the new institutional model that is under the administration of government authorities. Although trust is a key element in other phases of a governance transformation (Gelcich et al. 2010), trust building is also one of the key areas for the institutionalization of a governance transformation to be successful. Trust is a factor that is increasingly receiving more attention in the fisheries governance literature (Eggert et al. 2018) and can be interpreted as "the extent to which a person is confident in, and willing to act on the basis of, the words, actions and decisions of another" (McAllister 1995:25).

In the case of the new Chilean fisheries law, trust is a core issue, because it is not possible to coordinate all activities, integrate policy objectives across sectors, and ensure cooperative incentives without a reasonable level of trust among the affected parties. In the same line of reasoning, this EA process signals the urgency of undertaking adjustments regarding the levels of participation and representativeness of all key stakeholders in the management of a fishery as a way to build trust. This recommendation is not new; research with lobster fishers in Maine also suggests that increased participation and a better understanding of power dynamics could build trust and overcome persistent barriers (Ebel et al. 2018). Specific recommendations that emerge from the EA process to improve trust involve a legal reform to allow a flexible number of participants in management committees as a way to link membership to the overall number of fishers. The EA also signals the need to improve government practices to supervise the selection process of artisanal representatives. In essence, the EA highlights the importance of considering the redistribution of trust and power as a way to support the new trajectories so that different actors and institutions do not become barriers of change or drive the transformation in unintended ways (Özen and Özen 2009).

A second key insight from the EA process is the importance of being able to secure the provision of multiple knowledge systems (Berkes 2009) for the correct institutionalization of the governance transformation. Results signal that special attention must be placed on integrating adequate local and bureaucratic knowledge into the new decision-making system. In the Chilean governance transformation, explicit ways to include local and bureaucratic knowledge, in addition to a larger diversity of scientific knowledge, which is currently constrained to biological knowledge aimed at stock assessment and defining maximum sustainable yields, should be designed. Incorporating a diversity of knowledge systems is considered key for the "triggering" and "preparing for change" phases of a governance transformation (Olsson et al. 2008, Gelcich et al. 2010); however, results show that it is also a key condition for institutionalizing transformations.

The EA process was useful for identifying that the governance transformation underestimated the difficulties not only of successfully integrating different types of knowledge (scientific/ local/bureaucratic), but also of securing its provision (Abreu et al. 2017). Tackling knowledge coproduction in a successful way will ideally improve the decision-making process, generating more socially robust and legitimized management alternatives (Prager and McKee 2015). Specific recommendations on including multiple knowledge systems that emerge from the EA involve improving operational aspects such as the promotion of joint sessions of the scientific and management committees and hiring experts and conducting studies on specific economic and social issues. Most importantly, the EA process provided key information that allows us to start a timely discussion aimed at fine-tuning how knowledge systems are considered and integrated into management plans.

The EA process also highlighted the importance of providing adequate financial resources and capacities for the implementation of the governance transformation. Institutionalizing transformations is likely to be resource intensive and time consuming (Moore et al. 2014). For instance, in Chile, capacity development needs to be a priority, an issue that needs to be placed firmly on the agenda for governance transformation to be effective. To improve capacities at different levels throughout the implementation and monitoring of management plans, Chile could draw on the recent interest from philanthropic donors to invest in the Chilean fisheries sector, e.g., Walton Chile strategy 2016 (https://www.waltonfamilyfoundation.org/our-work/environment/ oceans). In essence, it is critical to recognize that long-term investments are key for governance transformations to be realized.

Implementing a governance transformation is a long-term endeavor, which involves building capacities, establishing viable institutions, and triggering major societal changes. Nevertheless, countries tend to operate on a short-term horizon, in which the resource management task seems to be over once a new policy is approved. We have shown that EA processes are a fundamental tool to encourage that governance transformation processes are not seen as an end point. In recognizing a longer time frame, EAs bring a sense of reality, informed by social science, that allows us to understand progress in the implementation of governance transformations, by identifying rigidities that fail to accommodate emerging realities.

Responses to this article can be read online at: http://www.ecologyandsociety.org/issues/responses. php/10517

\footnotetext{
Acknowledgments:

We acknowledge support from the "Concurso de Politicas PúblicasPUC," the Walton Family Foundation, and FONDECYT 1160145. We were also supported by "Financiamiento Basal FB-0002," the Millennium Nucleus Center for the Study of Multiple-Drivers on Marine Socio-Ecological Systems (MUSELS), and the CESIEP center funded by the Millennium Research Initiative. We thank the Pew Marine Conservation Fellowship Program. We sincerely thank Barbara Peñafiel who was key to the success of this whole project and all the stakeholders who actively participated in the different stages of the early assessment. We thank two anonymous referees who greatly improved the paper. The study complied with ethical clearance associated with the Center of Applied Ecology and Sustainability, Pontificia Universidad Católica de Chile.
} 


\section{LITERATURE CITED}

Abreu, J. S., C. Domit, and C. A. Zappes. 2017. Is there dialogue between researchers and traditional community members? The importance of integration between traditional knowledge and scientific knowledge to coastal management. Ocean \& Coastal Management 141:10-19. http://dx.doi.org/10.1016/j. ocecoaman.2017.03.003

Ayers, A. L., and J. N. Kittinger. 2014. Emergence of comanagement governance for Hawai'i coral reef fisheries. Global Environmental Change 28(9):251-262. http://dx.doi.org/10.1016/ j.gloenvcha.2014.07.006

Bennett, C. J., and M. Howlett. 1992. The lessons of learning: reconciling theories of policy learning and policy change. Policy Sciences 25:275-294. http://dx.doi.org/10.1007/BF00138786

Berkes, F. 2009. Evolution of co-management: role of knowledge generation, bridging organizations and social learning. Journal of Environmental Management 90:1692-1702. http://dx.doi.org/10.1016/ j.jenvman.2008.12.001

Cerna, L. 2013. The nature of policy change and implementation: a review of different theoretical approaches. Organisation for Economic Co-operation and Development, Paris, France.

Cinner, J. E., and T. R. McClanahan. 2015. A sea change on the African coast? Preliminary social and ecological outcomes of a governance transformation in Kenyan fisheries. Global Environmental Change 30:133-139. http://dx.doi.org/10.1016/j. gloenvcha.2014.10.003

Convention on Biological Diversity. 2011. Ecosystem approach. Secretariat of the the Convention on Biological Diversity, Montreal, Quebec, Canada. [online] URL: http://www.cbd.int/ ecosystem/

Ebel, S. A., C. M. Beitl, J. Runnebaum, R. Alden, and T. R. Johnson. 2018. The power of participation: challenges and opportunities for facilitating trust in cooperative fisheries research in the Maine lobster fishery. Marine Policy 90:47-54. http://dx.doi.org/10.1016/j.marpol.2018.01.007

Edelenbos, J., A. van Buuren, and N. van Schie. 2011. Coproducing knowledge: joint knowledge production between experts, bureaucrats and stakeholders in Dutch water management projects. Environmental Science \& Policy 14 (6):675-684. http://dx.doi.org/10.1016/j.envsci.2011.04.004

Eggert, H., M. Kataria, and E. Lampi. 2018. Who can be trusted to manage the fish? A study comparing trust between stakeholders. Land Economics 94:354-367. http://dx.doi. org/10.3368/le.94.3.354

Evans, L. S., K. Brown, and E. H. Allison. 2011. Factors influencing adaptive marine governance in a developing country context: a case study of southern Kenya. Ecology and Society 16 (2):21. http://dx.doi.org/10.5751/ES-04084-160221

Folke, C., S. R. Carpenter, B. Walker, M. Scheffer, T. Chapin, and J. Rockström. 2010. Resilience thinking: integrating resilience, adaptability and transformability. Ecology and Society 15(4):20. http://dx.doi.org/10.5751/ES-03610-150420

Food and Agriculture Organization of the United Nations (FAO). 2015. Enfoque Ecosistémico Pesquero: Conceptos Fundamentales y su Aplicación en pesquería de Pequeña Escala en América Latina. FAO Documento Técnico de Pesca y Acuicultura 592. FAO, Rome, Italy. [online] URL: http://www.oceandocs.org/handle/1834/7413? locale-attribute $=$ ru

Food and Agriculture Organization of the United Nations (FAO). 2016. The state of world fisheries and aquaculture 2016: contributing to food security and nutrition for all. FAO, Rome, Italy. [online] URL: http://www.fao.org/3/a-i5555e.pdf

Gelcich, S. 2014. Towards polycentric governance of small-scale fisheries: insights from the new 'Management Plans' policy in Chile. Aquatic Conservation: Marine and Freshwater Ecosystems 24:575-581. http://dx.doi.org/10.1002/aqc.2506

Gelcich, S., J. Cinner, C. J. Donlan, S. Tapia-Lewin, N. Godoy, and J. C. Castilla. 2017. Fishers' perceptions on the Chilean coastal TURF system after two decades: problems, benefits, and emerging needs. Bulletin of Marine Science 93(1):53-67. http://dx. doi.org/10.5343/bms.2015.1082

Gelcich, S., T. P. Hughes, P. Olsson, C. Folke, O. Defeo, M. Fernández, S. Foale, L. H. Gunderson, C. Rodríguez-Sickert, M. Scheffer, R. S. Steneck, and J. C. Castilla. 2010. Navigating transformations in governance of Chilean marine coastal resources. Proceedings of the National Academy of Sciences of the United States of America 107(39):16794-16799. http://dx.doi. org/10.1073/pnas.1012021107

Gelcich, S., L. Peralta, C. J. Donlan, N. Godoy, V. Ortiz, S. TapiaLewin, C. Vargas, A. Kein, J. C. Castilla, M. Fernandez, and F. Godoy. 2015. Alternative strategies for scaling up marine coastal biodiversity conservation in Chile. Maritime Studies 14:5. http:// dx.doi.org/10.1186/s40152-015-0022-0

Gelcich, S., F. Reyes-Mendy, R. Arriagada, and B. Castillo. 2018. Assessing the implementation of marine ecosystem based management into national policies: insights from agenda setting and policy responses. Marine Policy 92:40-47. http://dx.doi. org/10.1016/j.marpol.2018.01.017

Gunderson, L. H., and C. S. Holling. 2002. Panarchy: understanding transformations in human and natural systems. Island, Washington, D.C., USA.

Gutiérrez, N. L., R. Hilborn, and O. Defeo. 2011. Leadership, social capital and incentives promote successful fisheries. Nature 470:386-389. http://dx.doi.org/10.1038/nature09689

Leal, C. P., R. A. Quiñones, and C. Chavez. 2010. What factors affect the decision-making process when setting TACs? The case of Chilean fisheries. Marine Policy 34:1183-1195. http://dx.doi. org/10.1016/j.marpol.2010.04.002

McAllister, D. J. 1995. Affect- and cognition-based trust as foundations for interpersonal cooperation in organizations. Academy of Management Journal 38(1):24-59. http://dx.doi. org/10.2307/256727

Ministerio de Economía, Fomento y Turismo, Subsecretaría de Pesca y Acuicultura. 2013. Ley $N^{\circ}$ 20.657. Modifica en el ámbito de la sustentabilidad de recursos hidrobiológicos, acceso a la actividad pesquera industrial y artesanal y regulaciones para la investigación y fiscalización, la ley general de pesca y acuicultura contenida en la ley $n^{\circ} 18.892$ y sus modificaciones. Republica de Chile, Santiago, Chile. 
Moore, M.-L., O. Tjornbo, E. Enfors, C. Knapp, J. Hodbod, J. A. Baggio, A. Norström, P. Olsson, and D. Biggs. 2014. Studying the complexity of change: toward an analytical framework for understanding deliberate social-ecological transformations. Ecology and Society 19(4):54. http://dx.doi.org/10.5751/ ES-06966-190454

Olsson, P., C. Folke, and F. Berkes. 2004. Adaptive comanagement for building resilience in social-ecological systems. Environmental Management 34:75-90. http://dx.doi.org/10.1007/ $\underline{\mathrm{s} 00267-003-0101-7}$

Olsson, P., C. Folke, and T. P. Hughes. 2008. Navigating the transition to ecosystem-based management of the Great Barrier Reef, Australia. Proceedings of the National Academy of Sciences of the United States of America 105:9489-9494. http://dx.doi. org/10.1073/pnas.0706905105

Olsson, P., L. H. Gunderson, S. R. Carpenter, P. Ryan, L. Lebel, C. Folke, and C. S. Holling. 2006. Shooting the rapids: navigating transitions to adaptive governance of social-ecological systems. Ecology and Society 11(1):18. http://dx.doi.org/10.5751/ ES-01595-110118

Ostrom, E. 1990. Governing the commons: the evolution of institutions for collective action. Cambridge University Press, New York, New York, USA. http://dx.doi.org/10.1017/CBO9780511807763

Özen, Ş., and H. Özen. 2009. Peasants against MNCs and the state: the role of the Bergama struggle in the institutional construction of the gold-mining field in Turkey. Organization 16 (4):547-573. http://dx.doi.org/10.1177/1350508409104508

Patterson, J., K. Schulz, J. Vervoort, S. van der Hel, O. Widerberg, C. Adler, M. Hurlbert, K. Anderton, M. Sethi, and A. Barau. 2017. Exploring the governance and politics of transformations towards sustainability. Environmental Innovation and Societal Transitions 24:1-16. http://dx.doi.org/10.1016/j.eist.2016.09.001

Prager, K., and A. McKee. 2015. Co-production of knowledge in soils governance. International Journal of Rural Law and Policy 1:1-17. http://dx.doi.org/10.5130/ijrlp.i1.2015.4352

Pressman, J., and A. Wildavsky. 1984. Implementation. Third edition. University of California Press, Berkeley, California, USA.

Reyes, F., S. Gelcich, and M. Ríos. 2017. Problemas globales, respuestas locales: planes de manejo como articuladores de un sistema de gobernabilidad policéntrica de los recursos pesqueros. Pages 121-155 in "Propuestas para Chile" Concurso Políticas Públicas 2016. Pontificia Universidad Católica de Chile, Santiago, Chile. [online] URL: http://politicaspublicas.uc.cl/wp-content/ uploads/2017/04/CAP.-4.pdf

Ríos, M. 2015. Ley de Pesca 20.657 y misceláneas: avances y desafios en su implementación. Serie Informe Económico 252. Libertad y Desarrollo, Santiago, Chile.

Walker, B. H., N. Abel, J. M. Anderies, and P. Ryan. 2009. Resilience, adaptability, and transformability in the GoulburnBroken Catchment, Australia. Ecology and Society 14(1):12. http://dx.doi.org/10.5751/ES-02824-140112
Walker, B., C. S. Holling, S. R. Carpenter, and A. Kinzig. 2004. Resilience, adaptability and transformability in social-ecological systems. Ecology and Society 9(2):5. http://dx.doi.org/10.5751/ ES-00650-090205

Westley, F., P. Olsson, C. Folke, T. Homer-Dixon, H. Vredenburg, D. Loorbach, J. Thompson, M. Nilsson, E. Lambin, J. Sendzimir, B. Banerjee, V. Galaz, and S. van der Leeuw. 2011. Tipping toward sustainability: emerging pathways of transformation. AMBIO 40 (7):762-780. http://dx.doi.org/10.1007/s13280-011-0186-9

Westley, F. R., O. Tjornbo, L. Schultz, P. Olsson, C. Folke, B. Crona, and Ö. Bodin. 2013. A theory of transformative agency in linked social-ecological systems. Ecology and Society 18(3):27. http://dx.doi.org/10.5751/ES-05072-180327 